\title{
Antimicrobial activities of commercial nanoparticles against an environmental soil microbe, Pseudomonas putida KT2440 Priyanka Gajjar ${ }^{1}$, Brian Pettee ${ }^{2}$, David W Britt ${ }^{1}$, Wenjie Huang ${ }^{3}$, William P Johnson*4 and Anne J Anderson*2
}

Address: 'Department of Biological Engineering, Utah State University, Logan Utah 84321, USA, ${ }^{2}$ Department of Biology, Utah State University, Logan Utah 84321, USA, ${ }^{3}$ Chemical Engineering, University of Utah, Salt Lake City, Utah 84112, USA and ${ }^{4}$ Geology \& Geophysics, University of Utah, Salt Lake City Utah 84112, USA

Email: Priyanka Gajjar - pgajjar@aggiemail.usu.edu; Brian Pettee - bpettee@hotmail.com; David W Britt - dbritt@cc.usu.edu; Wenjie Huang - wenjie.huang@utah.edu; William P Johnson* - william.johnson@utah.edu; Anne J Anderson* - anderson@biology.usu.edu

* Corresponding authors

Published: 26 June 2009

Journal of Biological Engineering 2009, 3:9 doi:10.1186/1754-1611-3-9

This article is available from: http://www.jbioleng.org/content/3/I/9

(C) 2009 Gajjar et al; licensee BioMed Central Ltd.

This is an Open Access article distributed under the terms of the Creative Commons Attribution License (http://creativecommons.org/licenses/by/2.0), which permits unrestricted use, distribution, and reproduction in any medium, provided the original work is properly cited.

\begin{abstract}
Background: The release of heavy metal-containing nanoparticles (NP) into the environment may be harmful to the efficacy of beneficial microbes that function in element cycling, pollutant degradation and plant growth. Nanoparticles of $\mathrm{Ag}, \mathrm{CuO}$ and $\mathrm{ZnO}$ are of interest as antimicrobials against pathogenic bacteria. We demonstrate here their antimicrobial activity against the beneficial soil microbe, Pseudomonas putida KT2440.
\end{abstract}

Results: Toxicity was detected in a KT2440 construct possessing a plasmid bearing the luxAB reporter genes. "As manufactured" preparations of nano- $\mathrm{Ag},-\mathrm{CuO}$ and $-\mathrm{ZnO}$ caused rapid dosedependent loss of light output in the biosensor. Cell death accompanied loss in Lux activity with treatments by nano- $\mathrm{Ag}$ and $-\mathrm{CuO}$, but with $-\mathrm{ZnO}$ the treatments were bacteriostatic rather than bactericidal. Bulk equivalents of these products showed no inhibitory activity, indicating that particle size was determinant in activity. Flow Field-Flow Fractionation (FIFFF) of an aqueous suspension of the nano- $\mathrm{CuO}$ and $\mathrm{ZnO}$ revealed a small proportion of $5 \mathrm{~nm} \mathrm{NP}$ and aggregated particulates with sizes ranging between $70 \mathrm{~nm}$ and $300 \mathrm{~nm}$; the majority portion of material was aggregated into particles larger than $300 \mathrm{~nm}$ in size. Thus within the commercial preparation there may be microbially active and inactive forms.

Conclusion: The "as-made" NP of $\mathrm{Ag}, \mathrm{CuO}$ and $\mathrm{ZnO}$ have toxic effects on a beneficial soil microbe, leading to bactericidal or bacteriostatic effects depending on the NP employed. The lack of toxicity from bulk materials suggests that aggregation of the NP into larger particles, possibly by factors present in the environment may reduce their nontarget antimicrobial activity.

\section{Background}

Nanotechnology has attracted global attention because nanoparticles (NP) have properties unique from their bulk equivalents. $\mathrm{NP}$ of $\mathrm{Ag}, \mathrm{CuO}$ and $\mathrm{ZnO}$ are being used industrially for several purposes including amendments to textiles, cosmetics, sprays, plastics and paints [1]. A common feature of these three NP is their antimicrobial activity [2-8]. The antimicrobial activity of NP largely has been studied with human pathogenic bacteria, mainly Escherichia coli and Staphylococcus aureus. Nano-Ag is 
inhibitory to E. coli $[5,9-16]$ and $S$. aureus $[5,9,12,16]$. These microbes also are sensitive to nano-CuO and nano$\mathrm{ZnO}[17,18]$.

$\mathrm{NP}$ of $\mathrm{Ag}, \mathrm{CuO}$ and $\mathrm{ZnO}$ are reported to attack bacterial membranes. Short exposure of E. coli cells to nano-Ag destabilizes the outer membrane, collapses the plasma membrane potential and decreases ATP [10]. Pits in E. coli cell walls were observed after nano-Ag treatment [13] and promoted release of green fluorescent protein from transformed E. coli cells [14]. Exposure of E. coli to nano-ZnO also causes loss in membrane integrity [6]. Likewise, toxicity of $\mathrm{NP}$ of $\mathrm{CuO}$ and $\mathrm{ZnO}$ are connected with cell membrane damage [17].

NP action may be due in part to their release of free ions. Heavy metal ions have diverse effects on bacterial cell function. For $\mathrm{Cu}$ ions, the mechanism may involve oxidative stress [8]. The redox cycling of $\mathrm{Cu}$ ions results in depletion of glutathione and affects the sulfhydryl groups of proteins causing DNA damage and lipid oxidation [7]. Like $\mathrm{Cu}, \mathrm{Zn}$ also is an essential element for cells; levels of $\mathrm{Zn}$ above the essential threshold level inhibit bacterial enzymes including dehydrogenase [19] and certain protective enzymes, such as thiolperoxidase, and glutathione reductase [20]. Zn inhibition of NADH oxidase is proposed to impede the respiratory chain of E. coli [21]. Additionally, loss of membrane potential is associated with inhibition by Zn ions at cytochrome c oxidase in Rhodobacter sphaeroides [22]. Ag ions inactivate proteins with SH groups and prevent the ability of DNA to replicate [23]. Holt and Bard [24] propose that NADH dehydrogenase in the electron transport chain of $E$ coli is inhibited by $\mathrm{Ag}$ ions.

Extensive use and increasing demand for NP will lead to their accumulation in the environment, especially in landfills and their water effluents. Control of pathogenic microbes by antimicrobial NP is a promising approach to defeat the multiresistant pathogens such as methicillinresistant $S$. aureus [18]. However, nontarget effects on the populations of microbes that play beneficial roles in the environment could have negative consequences. Many microbes have essential roles in element cycling, (carbon, sulfur, nitrogen, etc.), while others degrade pollutants and promote plant growth [25-31]. Nowack and Bucheli [32] found little published information about the release of $\mathrm{NP}$ in the environment in their efforts to model the risk of Ag NP. Novel and unprecedented sources are likely: recently, commercially available nano-Ag-treated socks were found to release Ag upon washing the socks [33]. Concern for nontarget effects of environmental accumulation of Ag has been raised [34].
The toxicity of NP against environmental microbes has been little studied. Vibrio fisheri has been used because of its natural light emitting property in assessment of toxicity and Bacillus subtilis has been examined as an example of a spore-forming bacterium $[4,5,17]$. The aim of this study was to evaluate the antimicrobial activity of nano-Ag, nano-CuO and nano-ZnO using a biosensor constructed in Pseudomonas putida KT2440. This pseudomonad is beneficial in the environment because of its bioremediation potential and it is a strong root colonizer $[25,35,36]$. The biosensor was constructed to emit light from $l u x A B$ genes under the control of a promoter containing a single heavy metal binding domain (MTCGHC). Because the luciferase encoded by luxAB requires $\mathrm{FMNH}_{2}$ as a substrate, expression from this promoter permits light output dependent on the energy status of the cells [37].

We report on the responses of the biosensor to NP of Ag, $\mathrm{CuO}$ and $\mathrm{ZnO}$ in comparison with the effects of bulk equivalents and free metal ions. We examined how loss of Lux activity correlated with changes in culturability of the cell as an effort to understand more of the potential environmental impacts of NP, a need discussed by Nowack and Bucheli [32]. We also document the sizes of the NP in aqueous suspension of the nano-metal oxides through the use of Flow Field-Flow Fractionation (FIFFF); aggregation of commercial preparations of NP is commonly reported.

\section{Methods \\ Chemicals}

ATTOSTAT (NLC Laboratories, Salt Lake City, UT) was used as the nano-Ag source, with NP of a reported size 10 $\mathrm{nm}$ and a concentration of $30 \mathrm{mg} \mathrm{Ag} / \mathrm{L}$. The bulk $\mathrm{Ag}$ source was from Alfa Aesar, Ward Hill, MA, with a reported particle size of $44,000 \mathrm{~nm}$. Bulk and NP of $\mathrm{CuO}$ and $\mathrm{ZnO}$ were purchased from Sigma-Aldrich, St. Louis, $\mathrm{MO}$. The reported "as manufactured" sizes were: nano$\mathrm{CuO}, 33 \mathrm{~nm}$; nano-ZnO, 50-70 nm; bulk $\mathrm{CuO}, 8000-$ $9000 \mathrm{~nm}$; and $\mathrm{ZnO}$, less than $1000 \mathrm{~nm}$. Exposure to ions was from solutions of $\mathrm{CuCl}_{2}, \mathrm{Zn}\left(\mathrm{NO}_{3}\right)_{2}$ and $\mathrm{AgNO}_{3}$. All solutions were prepared in distilled, sterile water.

\section{Biosensor construction and use}

The biosensor was constructed in strain P. putida KT2440 to harbor a plasmid with a $\operatorname{lux} A B$ fusion to a Cu-responsive promoter [Pettee et al., unpublished]. Oligonucleotide primers were designed to amplify approximately 500 bps 5 ' to 100 bps 3' downstream of the translational start site at locus PP_0588 in wild type P. putida KT2440. The primers were: For, CGATGCGGTATTTGTTGATCT and Rev, AATCGCAGTGAGGATCTGCT. PCR products containing the PP_0588 promoter region were ligated to the promoterless luxAB::npt cassette in plasmid pCR2.1 5' bearing resistance genes for kanamycin and ampicillin (Invitrogen.com) in E. coli. Determination of the pro- 
moter orientation in the clones was achieved by PCR analysis using a primer to the $5^{\prime}$ end of the luxA gene in the reverse orientation and identifying PCR products when used with the 5' promoter primer of PP_0588, 5'-CGATGCGGTATTTGTTGATCT-3'. The luxA primer sequence was 5'-CAACCAAATTTTCCCCAAGA-3'. Positive clones were ultimately confirmed by the presence of Lux activity and ability to grow on kanamycin at $20 \mu \mathrm{g} / \mathrm{ml}$. The PP_0588 lux fusion was removed from the PCR2.1 vector and inserted into the stable plasmid pCPP45, bearing a resistance gene for tetracycline, for triparental mating into P. putida KT2440.

The PP_0588 cells were stored in $15 \%$ glycerol at $-80^{\circ} \mathrm{C}$. Logarithmic phase cells were generated by reculturing from an overnight culture grown in minimal medium $(\mathrm{MM})$ with shaking at $25^{\circ} \mathrm{C}$ to $\mathrm{OD} 600_{\mathrm{nm}}=0.1 \mathrm{MM}$ contained in $1 \mathrm{~L}$ : $10.5 \mathrm{~g} \mathrm{~K}_{2} \mathrm{HPO}_{4}, 4.5 \mathrm{~g} \mathrm{KH}_{2} \mathrm{PO}_{4}, 0.5 \mathrm{~g}$ sodium citrate $\left(2 \mathrm{H}_{2} \mathrm{O}\right), 1.0 \mathrm{~g}\left(\mathrm{NH}_{4}\right)_{2} \mathrm{SO}_{4}, 0.25 \mathrm{~g} \mathrm{MgSO}_{4} \cdot 7 \mathrm{H}_{2} \mathrm{O}$, and $2.0 \mathrm{~g}$ sucrose. The culture $(200 \mathrm{ml})$ was centrifuged at $10,000 \mathrm{~g}$ for $10 \mathrm{~min}$ and the cells were resuspended in 200 $\mathrm{ml}$ sterile distilled water and used immediately in the Lux assay. After dividing into $50 \mathrm{ml}$ aliquots in $125 \mathrm{ml}$ flasks, the suspensions were treated with NP, bulk material or ions at defined final concentrations or were left without treatment as a control. Initially the cells were treated with $0.1,1$ and $10 \mathrm{mg}$ metal $(\mathrm{M}) / \mathrm{L}$ to determine the sensitivity range. Subsequently doses were adjusted to determine the level at which toxicity was observed. Flasks were shaken at $200 \mathrm{rpm}$ and $25^{\circ} \mathrm{C}$ during the study. At defined times, $200 \mu \mathrm{l}$ of the suspensions were transferred in triplicate into well plates for Lux readings. The luciferase substrate, $1 \%$ decanal in ethanol, $10 \mu \mathrm{l}$, was added automatically in the L MAXII Luminometer (Molecular Devices Corporation, Sunnyvale CA). Light output was recorded with a 10 sec. exposure. Generally samples were assayed every 10 minutes up to $1 \mathrm{~h}$. At each sampling time, the Lux activity from three aliquots of the cell suspension was measured. Each treatment was replicated in three or more separate studies.

\section{Assessment of culturability}

Cells, after a 60 minute treatment with or without metal exposure, were assayed for culturability by dilution plating on salt-free Luria Broth (Difco, Sparks, MD) agar medium. Colonies were counted after $24 \mathrm{~h}$ incubation at $28^{\circ} \mathrm{C}$ and the colony forming units $(\mathrm{Cfu}) / \mathrm{ml}$ determined.

\section{Fractionation of nano-metal oxide particles}

An aqueous suspension of $10,000 \mathrm{mg} \mathrm{Cu} / \mathrm{L}$ of nano-CuO or nano-ZnO in sterile distilled water was filtered sequentially through sterile filters with pore sizes of 450 and 200 nm (Whatman Inc., Florham Park, NJ, USA). The filtrates were collected and diluted 5, 10, 100 or 1000-fold into cultures of KT2440 to determine effect on light output as described above. After 60 minutes of exposure cells were plated to determine culturability.

Flow Field-Flow Fractionation (FIFFF) and ICP-MS analysis Suspensions of "as manufactured" nano-CuO and $\mathrm{ZnO}$ were fractionated according to size using asymmetric FlFFF (AF4) (Postnova Analytics, Landsberg, Germany). The operational procedure for FlFFF followed published procedures [38-40]. In FlFFF, carrier fluid (and introduced sample) flowed down the length of a channel bounded along its length by a membrane. NP size separation occurred in the presence of a cross-flow field perpendicular to the flow axis, in which the particles migrated differentially across the channel and aligned themselves within different streamlines in the laminar parabolic flow field, resulting in different-sized particles being carried toward the channel exit at different velocities. Under the FlFFF conditions used as described in Table 1, the elution time of a NP was proportional to its size; two experimental conditions were used to best tune the instrument to particle size of interest. Operating condition I (Table 1) was used for fractionation in the size range between 10 to 250 $\mathrm{nm}$, and was calibrated using colloidal gold and fluorescent latex beads with known sizes (10, 98 and $200 \mathrm{~nm}$, respectively). Operating condition II (Table 1) was used for fractionating particles smaller than $10 \mathrm{~nm}$, and was calibrated using colloidal silver and colloidal gold with known sizes ( $5 \mathrm{~nm}$ and $10 \mathrm{~nm}$ ). NPs with high diffusivity (small size) relative to the applied cross flow were eluted in the so-called "void peak". Particles with high fluid drag (large size) relative to diffusivity were held against the membrane until elution in the so-called "rinse peak" upon relaxation of the cross flow.

The dimensions of the asymmetric FlFFF channel used were $27.3 \mathrm{~cm}$ in length, $224 \mu \mathrm{m}$ in thickness. The channel volume was $0.71 \mathrm{ml}$, calculated according to described methods [41]. The membrane used was made from regenerated cellulose (10 K Dalton pore size). Milli-Q water (Millipore System) with 2\% v/v FL-70 was used as carrier. The $\mathrm{pH}$ of the carrier solution was 8.93. Three detectors (UV absorbance, fluorescence and inductively coupled plasma mass spectrometry [ICP-MS]) were used in series downstream of the FIFFF to analyze the fractionated sample. FlFFF coupled with ICP-MS allowed online simultaneous determination of particle size distribution and elemental distribution of the nanomaterials [40]. The ICP-MS Agilent 7500 ce (Agilent Technologies Inc., Santa Claram, CA, USA) was used in continuous mode. The general operating parameters are summarized in Table 2.

\section{Results \\ Exposure to nano-Ag, bulk-Ag and $\mathrm{Ag}$ ions}

As shown in Fig. 1, nano-Ag was toxic to the biosensor. Treatments above $0.2 \mathrm{mg} \mathrm{Ag} / \mathrm{L}$ caused immediate loss in 
Table I: Operation conditions for separation of particles of different size by FIFF

\begin{tabular}{|c|c|c|c|c|c|c|}
\hline \multicolumn{7}{|c|}{ Operating conditions for particles $10-250 \mathrm{~nm}$} \\
\hline Focus step & Elution time min & $\begin{array}{l}\text { Flow rate } \\
\text { Tip } \mathrm{ml} / \mathrm{min}\end{array}$ & $\begin{array}{l}\text { Flow rate } \\
\text { Focus } \\
\mathrm{ml} / \mathrm{min}\end{array}$ & $\begin{array}{l}\text { Flow rate } \\
\text { Cross } \\
\mathrm{ml} / \mathrm{min}\end{array}$ & $\begin{array}{l}\text { Flow rate } \\
\text { Detector } \\
\mathrm{ml} / \mathrm{min}\end{array}$ & $\begin{array}{l}\text { Flow rate } \\
\text { Slot } \\
\mathrm{ml} / \mathrm{min}\end{array}$ \\
\hline Elution step & NA & 0.1 & 3.9 & 1 & 0.4 & 2.6 \\
\hline Stage I & 7 & 4 & NA & 1 & 0.4 & 2.6 \\
\hline Stage 2 & 5 & 3.7 & NA & 0.7 & 0.4 & 2.6 \\
\hline Stage 3 & 5 & 3.7 & NA & 0.7 & 0.4 & 2.6 \\
\hline Rinse step & 5 & 3 & 0 & 0 & 0.4 & 2.6 \\
\hline \multicolumn{7}{|c|}{ Operating conditions for particles less than $10 \mathrm{~nm}$} \\
\hline Focus step & Elution time min & $\begin{array}{l}\text { Flow rate } \\
\text { Tip } \mathrm{ml} / \mathrm{min}\end{array}$ & $\begin{array}{l}\text { Flow rate } \\
\text { Focus } \\
\mathrm{ml} / \mathrm{min}\end{array}$ & $\begin{array}{l}\text { Flow rate } \\
\text { Cross } \\
\mathrm{ml} / \mathrm{min}\end{array}$ & $\begin{array}{l}\text { Flow rate } \\
\text { Detector } \\
\mathrm{ml} / \mathrm{min}\end{array}$ & $\begin{array}{l}\text { Flow rate } \\
\text { Slot } \\
\mathrm{ml} / \mathrm{min}\end{array}$ \\
\hline Elution step & NA & 0.1 & 4.4 & 3.5 & 0.4 & 0.6 \\
\hline Stage I & 12 & 4.5 & NA & 3.5 & 0.4 & 0.6 \\
\hline Stage 2 & 0.5 & 3.0 & NA & 2 & 0.4 & 0.6 \\
\hline Stage 3 & 0.5 & 2.0 & NA & 1 & 0.4 & 0.6 \\
\hline Rinse step & 8 & 3 & 0 & 0 & 0.2 & 2.8 \\
\hline
\end{tabular}

The injection flow rate was $0.1 \mathrm{ml} / \mathrm{min}$, the time of injection $5 \mathrm{~min}$ and the time for transit of sample $\mathrm{I}$ min for both separation conditions. NA, not applicable.

light output (Fig. 1A). When treated with bulk Ag, no loss in Lux output was observed even for concentrations of 10 mg Ag/L (Fig. 1B). Cells also exhibited loss in light output with treatment from $\mathrm{Ag}$ ions with 1 and $10 \mathrm{mg} / \mathrm{L}$ doses (Fig. 1C). Treatment with a range of lower doses showed that $0.2 \mathrm{Ag}$ ion/L also caused rapid loss in light output (data not shown). Consequently, there was a sharp threshold between 0.1 and $0.2 \mathrm{mg} / \mathrm{L}$ for toxicity with the Ag ions.

The tables adjacent to the RLU graphs report the changes in culturability of the cells transferred to plating medium after 60 minutes of treatment compared with unchallenged controls. For treatment with nano-Ag and Ag ions, loss of Lux activity correlated with loss in culturability. No loss in Lux output or culturability was observed with exposure to bulk Ag. At $0.25 \mathrm{mg} / \mathrm{L}$ nano-Ag no culturable cells were obtained; with Ag ion a culturability threshold near $0.2 \mathrm{mg}$ Ag ion/L (data not shown) was determined.

\section{Exposure to nano-CuO, bulk-CuO and $\mathrm{Cu}$ ions}

The biosensor also showed loss in Lux activity when treated with nano-CuO and $\mathrm{Cu}$ ions but not with bulk CuO. Fig. 2A demonstrates that treatment with $10 \mathrm{mg} \mathrm{Cu} /$ $\mathrm{L}$ from the nano-CuO caused a time-dependent loss in light output whereas bulk $\mathrm{CuO}$ was inactive (Fig. 2B). Treatment with 1.0 and $0.1 \mathrm{mg} \mathrm{Cu} / \mathrm{L}$ nano- $\mathrm{CuO}$ caused no effect (Fig. 2A). Ten mg Cu/L nano-CuO rapidly reduced RLU, and a toxicity threshold showing rapid RLU reduction was observed between $5 \mathrm{mg}$ and $7 \mathrm{mg} \mathrm{Cu} / \mathrm{L}$ (data not shown). Toxicity of the $\mathrm{Cu}$ ion, from $\mathrm{CuCl}_{2}$, towards the biosensor was apparent at $1.0 \mathrm{mg} \mathrm{Cu} / \mathrm{L}$ with $0.1 \mathrm{mg} / \mathrm{L} \mathrm{hav}$ - ing little effect (Fig. 2C). A rapid RLU reduction was observed for $0.5 \mathrm{mg} / \mathrm{L}$ (data not shown). Thus, nano-CuO was about ten-fold less active than the free ions for the biosensor response. To confirm that toxicity with the $\mathrm{Cu}^{2+}$ was due to the metal ions rather than the $\mathrm{Cl}^{-}$, the biosensor was exposed to $\mathrm{Cl}^{-}$from $\mathrm{NaCl}$. At a dose level where $\mathrm{Cl}^{-}$ was at the same concentration as that from $\mathrm{CuCl}_{2}$ when $\mathrm{Cu}$ was present at $10 \mathrm{mg} / \mathrm{L}$ there was no observed toxicity (data not shown).

Loss in Lux correlated with loss in culturability upon exposure to $\mathrm{Cu}$ ions and reduced culturability upon exposure to nano- $\mathrm{CuO}$ at $10 \mathrm{mg} / \mathrm{L}$ treatment. Cell culturability did not decline with bulk $\mathrm{CuO}$ exposure.

\section{Exposure to nano-ZnO, bulk-ZnO and $\mathrm{Zn}$ ions}

Fig. 3A illustrates that treatment with 7 and $10 \mathrm{mg} \mathrm{Zn/L} \mathrm{of}$ nano-ZnO rapidly eliminated light output from the biosensor. Interestingly, lower nano- $\mathrm{ZnO}$ concentrations of 1.0 (Fig. 3A) and 5.0 (data not shown) increased light output above the control. With bulk $\mathrm{ZnO}$ no toxicity was

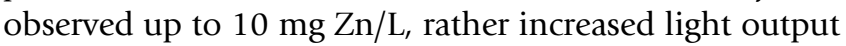
was observed (Fig. 3B). Treatment with 10 (not shown) and $1 \mathrm{mg} \mathrm{Zn/L} \mathrm{as} \mathrm{the} \mathrm{free} \mathrm{ion} \mathrm{(Fig.} \mathrm{3C)} \mathrm{caused} \mathrm{rapid} \mathrm{loss}$ in light output. The threshold value for reduction of Lux activity of the free ion was between 0.1 and $0.5 \mathrm{mg} / \mathrm{L}$. As with the nano- and bulk $\mathrm{ZnO}$, increased light output also was observed for the free ion, with activating concentrations observed between 0.1 and $0.05 \mathrm{mg} / \mathrm{L}$ of ionic $\mathrm{Zn}$.

None of the treatments with $\mathrm{Zn}$ caused complete loss in culturability, rather they were bacteriostatic. Cells grew 
Table 2: Description of operational conditions for ICP-MS of fractionated materials.

\begin{tabular}{|c|c|}
\hline \multicolumn{2}{|l|}{ OPERATIONAL CONDITIONS } \\
\hline RF power (W) & 1550 \\
\hline Plasma gas flow rate (L/min) & 15 \\
\hline Hydrogen flow rate $(\mathrm{mL} / \mathrm{min})$ & 2.5 \\
\hline Helium flow rate $(\mathrm{mL} / \mathrm{min})$ & 2.5 \\
\hline Carrier flow rate (L/min) & 0.9 \\
\hline Make-up gas (L/min) & 0.1 \\
\hline Auxiliary gas (L/min) & 0.9 \\
\hline Sample flow rate $(\mathrm{mL} / \mathrm{min})$ & 0.4 \\
\hline Acquisition time per isotope (sec) & 0.1 \\
\hline Repetition & 3 \\
\hline Total acquisition time for 19 isotopes (sec) & 2.85 \\
\hline Total running time $(\mathrm{sec})$ & 1880 \\
\hline \multicolumn{2}{|l|}{ Tuning solution: } \\
\hline$\%$ RSD & $<3 \%$ \\
\hline \multicolumn{2}{|l|}{ Sample nebulizer tubing: } \\
\hline Material & Tygon \\
\hline Internal diameter (mm) & 1.02 \\
\hline \multicolumn{2}{|l|}{ AF4 carrier tubing: } \\
\hline Material & PEEK \\
\hline Internal diameter $(\mathrm{mm})$ & 0.25 \\
\hline
\end{tabular}

from the $\mathrm{Zn}$-exposed samples at a delayed rate. Whereas colonies from the control cells could be counted in 2 days, those from cells exposed to zinc required at least 5 days. The culturability data shown in Fig. 3 are after 1 week of growth.

\section{Exposure to mixtures of nanoparticles}

Fig. 4A demonstrates that co-treatment of the biosensor with $0.1 \mathrm{mg}$ nano- $\mathrm{Ag} / \mathrm{L}$ plus $1.0 \mathrm{mg} / \mathrm{L}$ of nano-CuO caused a time-dependent loss in light output whereas the individual NP treatments had no effect. The adjacent culturability data are after 1 week of growth on the plate medium - the longer time was required as the combined treatment caused bacteriostasis. Cell culturability declined but was not reduced to zero upon exposure to this NP mixture. NP interaction promoting loss in Lux output was not observed in cotreatments with $1.0 \mathrm{mg} / \mathrm{L}$
nano-CuO plus $1.0 \mathrm{mg} / \mathrm{L}$ nano-ZnO or $0.1 \mathrm{mg}$ nano-Ag/L plus $1.0 \mathrm{mg} / \mathrm{L}$ nano-ZnO (Fig. 4B and 4C).

\section{Size determination of particles in aqueous suspensions of nano- $\mathrm{CuO}$ and nano-ZnO}

FlFFF of the $\mathrm{CuO}$ and $\mathrm{ZnO}$ NP filtrates obtained using filters with a $450 \mathrm{~nm}$ cut off showed the presence of structures smaller than $5 \mathrm{~nm}$ (Fig. 5A and 5B). The material remaining on the filter surface for both nano- $\mathrm{CuO}$ and $\mathrm{ZnO}$ (Fig 6A and 6B) contained poly-dispersed particulates in a broad size range from $70 \mathrm{~nm}$ to larger than 300 $\mathrm{nm}$, with the bulk being larger than $300 \mathrm{~nm}$, as demonstrated by the high ICP-MS counts during the rinse peak.

\section{Biosensor response to filtrates containing 5-200 nm particles from nano-CuO}

Treatment of the biosensor cells with the filtrates passing through both $450 \mathrm{~nm}$ and $200 \mathrm{~nm}$ filters from a suspension of nano-CuO at $10,000 \mathrm{mg} \mathrm{Cu} / \mathrm{L}$ caused dose dependent loss in light output. No toxicity was observed with a 100 -fold dilution of the filtrate but no light was emitted when cells were treated with the $\times 10$ diluted filtrate. The loss in Lux activity with the 10-fold diluted filtrate correlated with loss in culturability. Similarly, treatment with the filtrate prepared from $10,000 \mathrm{mg} \mathrm{Zn/L}$ from nano-ZnO at $\times 5$ and $\times 10$, but not $\times 100$ dilution, caused partial loss in light output. In contrast to the filtrate from the nano- $\mathrm{CuO}$, no change in culturability was observed for nano-ZnO (data not shown).

\section{Discussion}

The biosensor constructed in the environmental isolate $P$. putida KT2440 effectively and rapidly, within minutes, demonstrated dose-dependent toxicity of $\mathrm{NP}$ of $\mathrm{Ag}, \mathrm{CuO}$ and $\mathrm{ZnO}$. These findings illustrate that the toxicity was not restricted to bacteria with pathogenic potential. Rather an environmental isolate, studied because of its bioremediation potential, was affected. The $\mathrm{NP}$ of $\mathrm{Ag}, \mathrm{CuO}$ and $\mathrm{ZnO}$ were more toxic, causing loss of Lux activity in the biosensor, than their equivalent bulk materials indicating that the nano-size of the material was important. The findings that nano-Ag, nano-CuO and nano- $\mathrm{ZnO}$ reduced Lux activity were consistent with the observations by other groups that these NP caused bacterial membrane damage $[6,10,13]$. We speculate that such damage altered the membrane potential of the cell and, we presume, the availability of the $\mathrm{FMNH}_{2}$ required for the Lux activity. Consequently, Lux activity declined in the biosensor cells.

With Ag, the toxic doses of the NP and the ion were simi$\operatorname{lar}(\sim 0.2 \mathrm{mg} \mathrm{Ag} / \mathrm{L})$ in the KT2440 cells. For Cu, complete loss of light output required exposure to $10 \mathrm{mg} \mathrm{Cu} / \mathrm{L}$ from nano- $\mathrm{CuO}$ compared with $1.0 \mathrm{mg} \mathrm{Cu} / \mathrm{L}$ of the $\mathrm{Cu}$ ions. Similarly, 7-10 mg Zn/L was required for toxicity of nano$\mathrm{ZnO}$ compared to about a ten fold lower dose of $\mathrm{Zn}$ ions. 


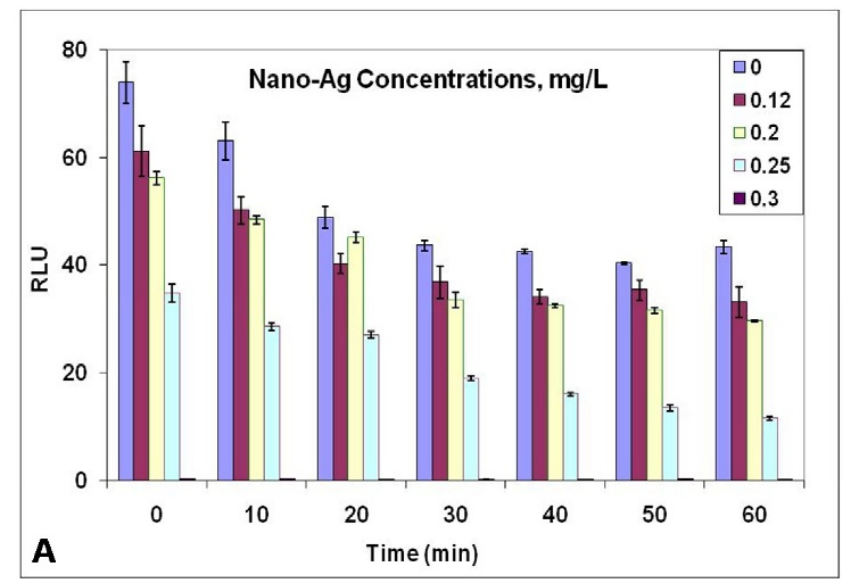

\begin{tabular}{|l|l|l|}
\hline Nano-Ag mg/L & $\log _{10}$ Cfu./ml & RLU at $60 \mathrm{~min}$ \\
\hline Control & $8.7 \pm 0.0$ & $43.4 \pm 2.2$ \\
\hline 0.12 & $8.7 \pm 0.0$ & $33.2 \pm 4.9$ \\
\hline 0.2 & $3.7 \pm 0.0$ & $29.7 \pm 0.2$ \\
\hline 0.25 & NCD & $11.6 \pm 0.6$ \\
\hline 0.3 & NCD & $0.2 \pm 0.2$ \\
\hline
\end{tabular}

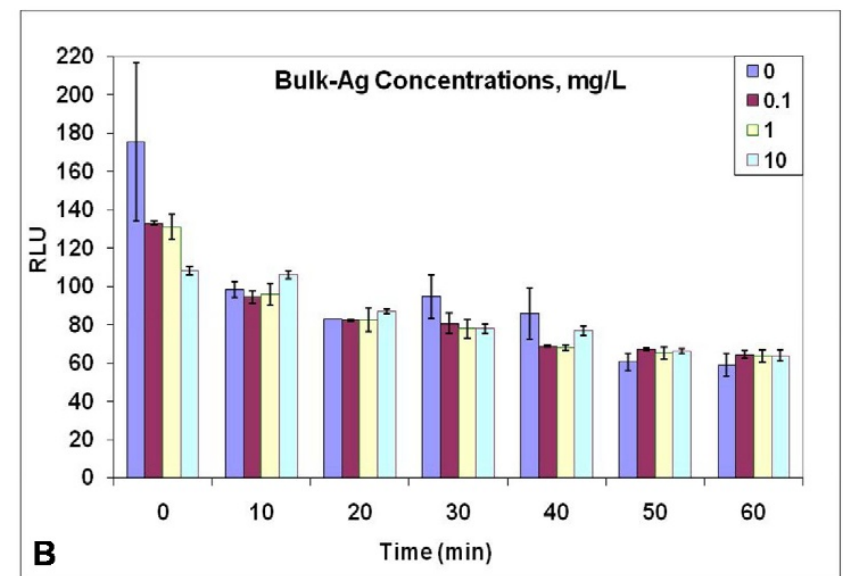

\begin{tabular}{|l|l|l|}
\hline Bulk-Ag mg/L & Log $_{10}$ Cfu./ml & RLU at $60 \mathrm{~min}$ \\
\hline Control & $8.7 \pm 0.0$ & $59.0 \pm 10.0$ \\
\hline 0.1 & $10.1 \pm 0.2$ & $64.5 \pm 3.7$ \\
\hline 1 & $9.6 \pm 0.3$ & $63.8 \pm 5.8$ \\
\hline 10 & $9.5 \pm 0.2$ & $64.0 \pm 5.3$ \\
\hline
\end{tabular}

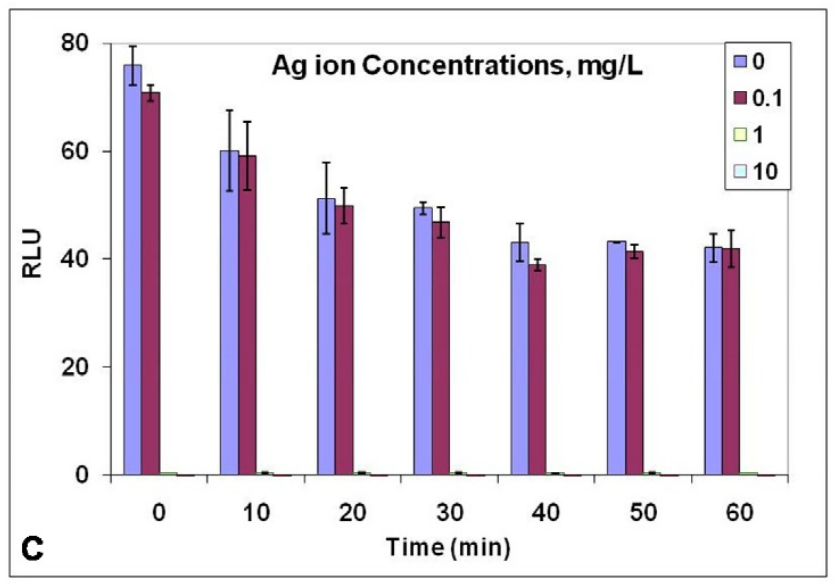

\begin{tabular}{|l|l|l|}
\hline Ag ion mg/L & $\log _{10}$ Cfu./mI & RLU at 60 min \\
\hline Control & $9.0 \pm 0.0$ & $39.9 \pm 3.8$ \\
\hline 0.1 & $8.8 \pm 0.1$ & $41.9 \pm 5.8$ \\
\hline 1 & NCD & $0.4 \pm 0.1$ \\
\hline 10 & NCD & $0.2 \pm 0.0$ \\
\hline
\end{tabular}

Figure I

Response of the P putida KT2440 biosensor to nano-Ag (A), bulk Ag (B) and Ag ions (C) at defined doses of mg Ag/L. Changes in Lux output (Relative light units RLU) and cell culturability (colony forming units Cfu) are shown. Studies were performed as described in Methods. NCD = No culturable cells detected. Data are from one study typical of at least three generated under the same conditions. Means and standard errors are shown. 


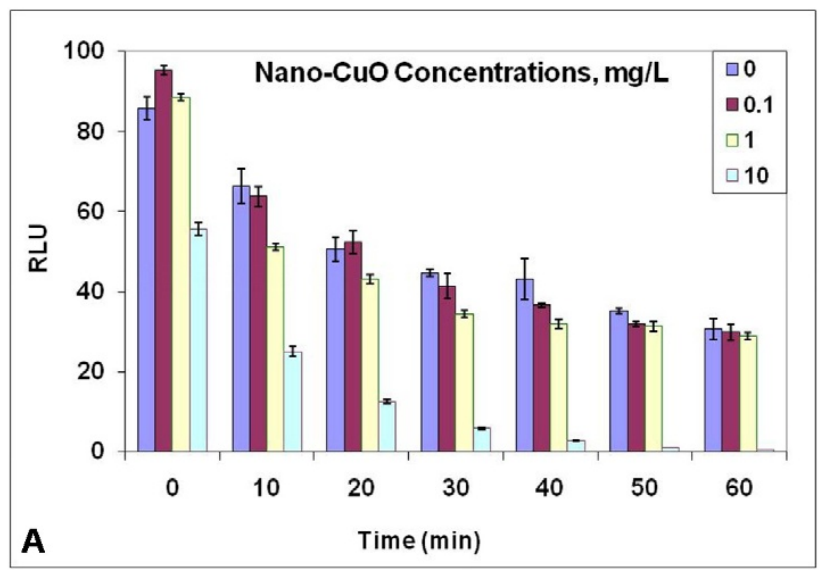

\begin{tabular}{|l|l|l|}
\hline Nano-CuO mg/L & $\log _{10} \mathrm{Cfu} . / \mathrm{ml}$ & RLU at $60 \mathrm{~min}$ \\
\hline Control & $8.7 \pm 0.0$ & $30.7 \pm 4.5$ \\
\hline 0.1 & $8.6 \pm 0.0$ & $29.8 \pm 3.4$ \\
\hline 1 & $10.0 \pm 0.5$ & $29.0 \pm 1.5$ \\
\hline 10 & $4.4 \pm 0.0$ & $0.4 \pm 0.0$ \\
\hline
\end{tabular}

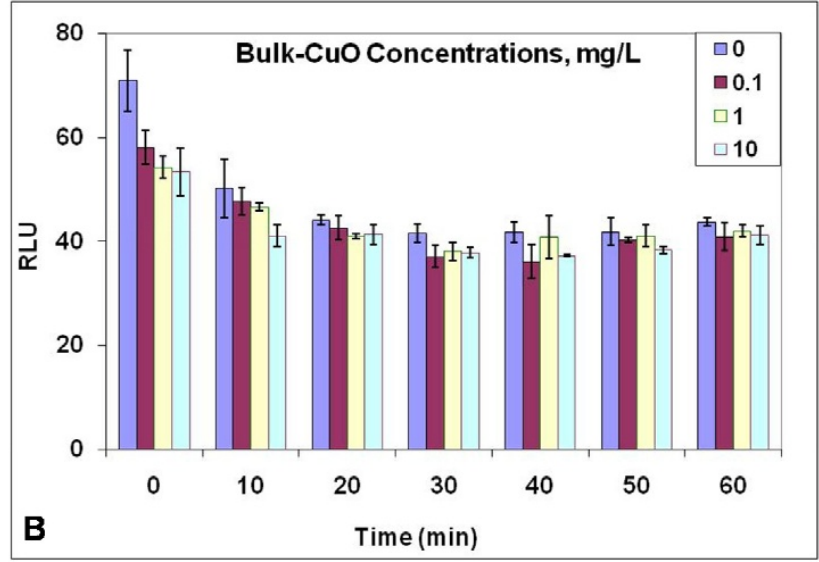

\begin{tabular}{|l|l|l|}
\hline Bulk-CuO mg/L & $\log _{10} \mathrm{Cfu} . / \mathrm{ml}$ & RLU at $60 \mathrm{~min}$ \\
\hline Control & $8.7 \pm 0.0$ & $43.8 \pm 1.2$ \\
\hline 0.1 & $8.8 \pm 0.2$ & $40.9 \pm 4.5$ \\
\hline 1 & $10.3 \pm 0.4$ & $42.0 \pm 2.0$ \\
\hline 10 & $9.0 \pm 0.0$ & $41.2 \pm 3.2$ \\
\hline
\end{tabular}

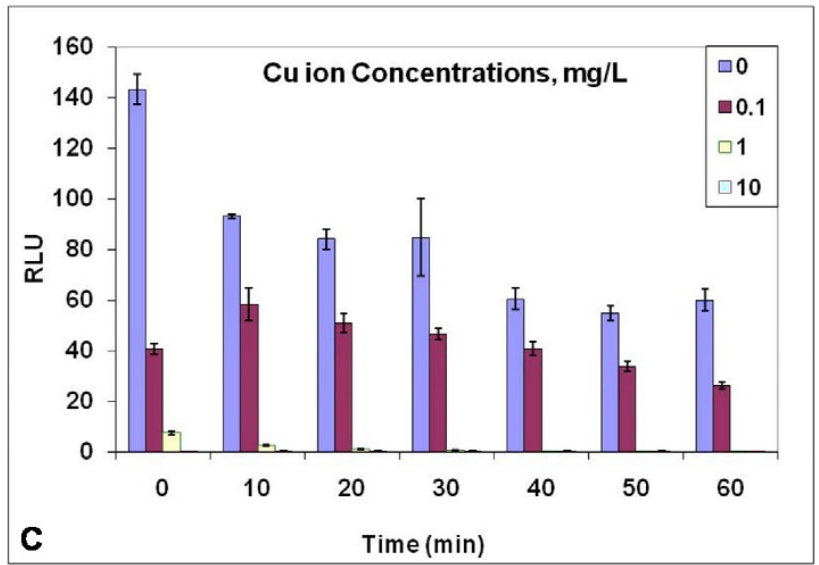

\begin{tabular}{|l|l|l|}
\hline Cu ion $\mathrm{mg} / \mathrm{L}$ & $\log _{10} \mathrm{Cfu} . / \mathrm{ml}$ & RLU at $60 \mathrm{~min}$ \\
\hline Control & $8.2 \pm 0.0$ & $52.0 \pm 5.1$ \\
\hline 0.1 & $7.7 \pm 0.5$ & $50.2 \pm 2.5$ \\
\hline 1 & NCD & $0.1 \pm 0.1$ \\
\hline 10 & NCD & $0.1 \pm 0.0$ \\
\hline
\end{tabular}

Figure 2

Response of the $P$ putida KT2440 biosensor to nano-CuO (A), bulk CuO (B) and Cu ions (C) at defined doses of mg Cu/L. Changes in Lux output (Relative light units RLU) and cell culturability (colony forming units Cfu) are shown. Studies were performed as described in Methods. NCD = No culturable cells detected. Data are from one study typical of at least three generated under the same conditions. Means and standard errors are shown. 


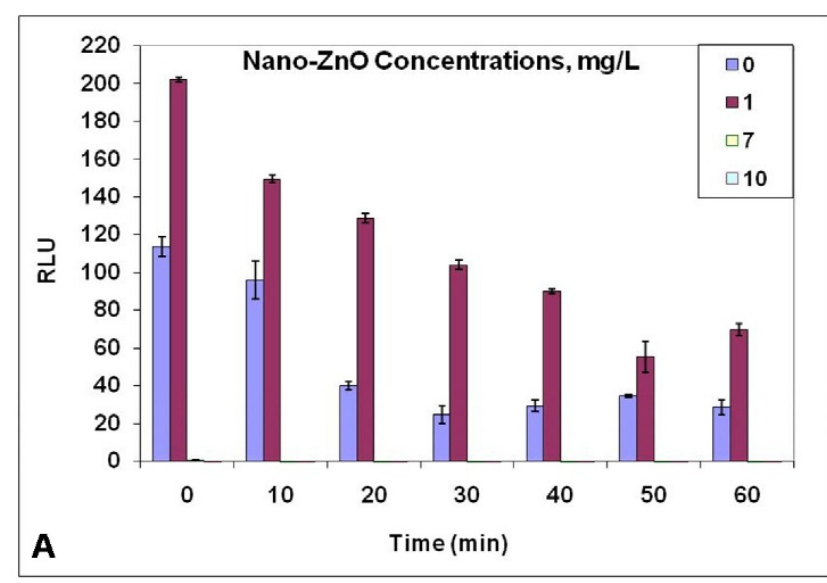

\begin{tabular}{|l|l|l|}
\hline Nano-ZnO mg/L & $\log _{10} \mathrm{Cfu} . / \mathrm{ml}$ & RLU at $60 \mathrm{~min}$ \\
\hline Control & $8.6 \pm 0.12$ & $28.5 \pm 6.9$ \\
\hline 1 & $8.7 \pm 0.3$ & $69.7 \pm 5.8$ \\
\hline 7 & $6.0 \pm 0.6$ & $0.1 \pm 0.1$ \\
\hline 10 & $6.4 \pm 1.9$ & $0.1 \pm 0.0$ \\
\hline
\end{tabular}

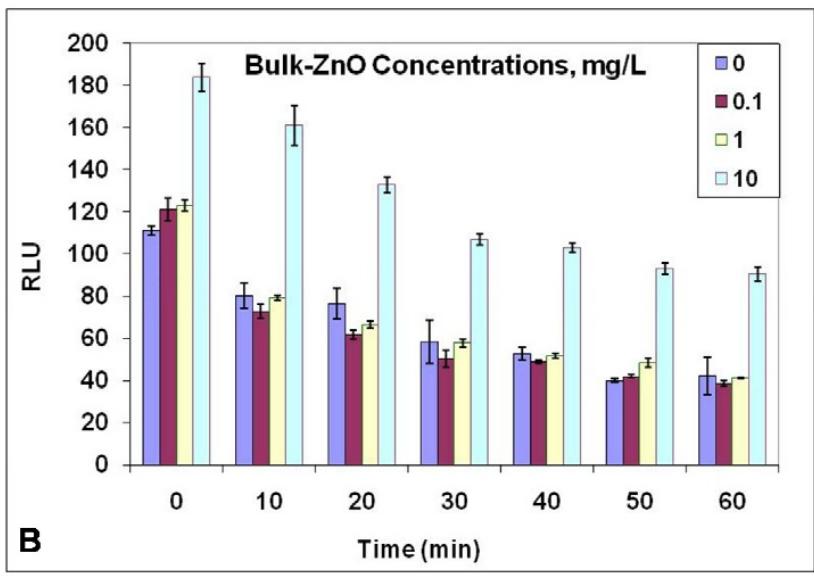

\begin{tabular}{|l|l|l|}
\hline Bulk-ZnO mg/L & Log $_{10}$ Cfu./ml & RLU at $60 \mathrm{~min}$ \\
\hline Control & $8.7 \pm 0.01$ & $42.4 \pm 15.2$ \\
\hline 0.1 & $9.3 \pm 0.3$ & $38.6 \pm 2.4$ \\
\hline 1 & $9.5 \pm 0.9$ & $41.5 \pm 0.5$ \\
\hline 10 & $10.6 \pm 1.2$ & $90.6 \pm 5.9$ \\
\hline
\end{tabular}

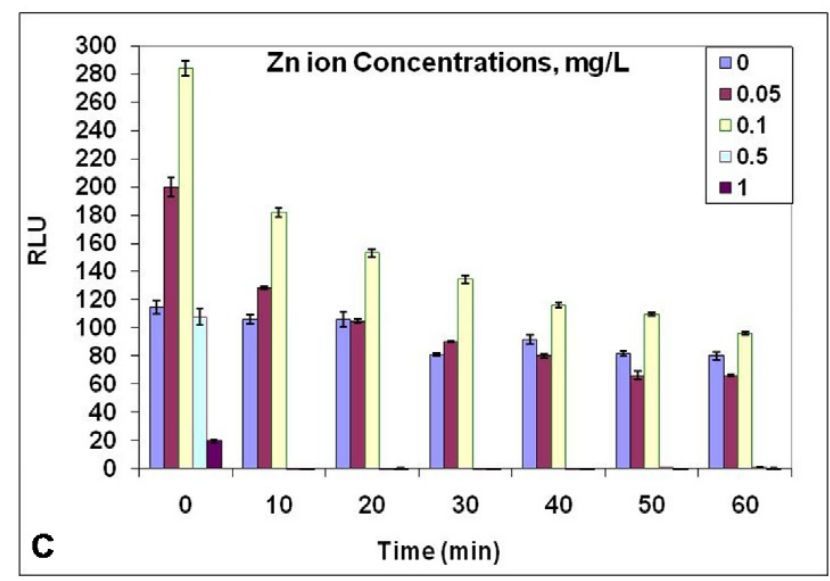

\begin{tabular}{|l|l|l|}
\hline Zn ion $\mathrm{mg} / \mathrm{L}$ & $\log _{10} \mathrm{Cfu} . / \mathrm{ml}$ & RLU at $60 \mathrm{~min}$ \\
\hline Control & $8.7 \pm 0.1$ & $79.9 \pm 4.8$ \\
\hline 0.05 & $9.5 \pm 0.4$ & $66.2 \pm 0.9$ \\
\hline 0.1 & $9.4 \pm 0.4$ & $96.3 \pm 1.9$ \\
\hline 0.5 & $7.5 \pm 1.2$ & $0.2 \pm 0.0$ \\
\hline 1 & $6.4 \pm 0.4$ & $0.1 \pm 0.1$ \\
\hline
\end{tabular}

Figure 3

Response of the P putida KT2440 biosensor to nano-ZnO (A), bulk ZnO (B) and $\mathrm{Zn}$ ions (C) at defined doses of $\mathbf{m g ~ Z n / L . ~ C h a n g e s ~ i n ~ L u x ~ o u t p u t ~ ( R e l a t i v e ~ l i g h t ~ u n i t s ~ R L U ) ~ a n d ~ c e l l ~ c u l t u r a b i l i t y ~ ( c o l o n y ~ f o r m i n g ~ u n i t s ~ C f u ) ~ a r e ~ s h o w n . ~ S t u d i e s ~}$ were performed as described in Methods. Data are from one study typical of at least three generated under the same conditions. Means and standard errors are shown. 


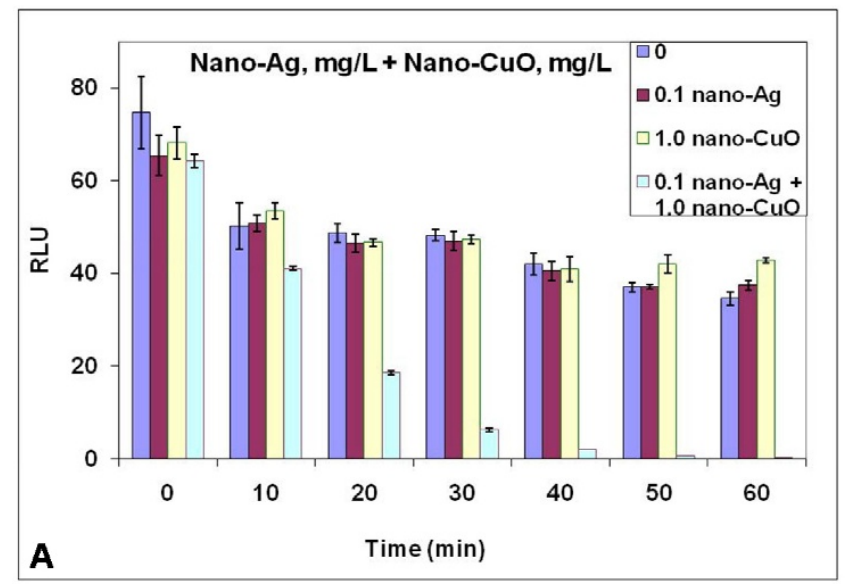

\begin{tabular}{|l|l|l|}
\hline $\begin{array}{l}\text { Nano-Ag, } \mathrm{mg} / \mathrm{L}+ \\
\text { Nano-CuO, } \mathrm{mg} / \mathrm{L}\end{array}$ & $\log _{10} \mathrm{Cfu} . / \mathrm{ml}$ & $\mathrm{RLU}$ at $60 \mathrm{~min}$ \\
\hline Control & $8.7 \pm 0.0$ & $34.7 \pm 2.5$ \\
\hline 0.1 nano-Ag & $7.7 \pm 0.0$ & $37.4 \pm 1.7$ \\
\hline 1.0 nano-CuO & $9.1 \pm 0.6$ & $42.8 \pm 0.8$ \\
\hline $\begin{array}{l}0.1 \text { nano-Ag } \\
+1.0 \text { nano-CuO }\end{array}$ & $5.3 \pm 0.1$ & $0.3 \pm 0.0$ \\
\hline
\end{tabular}

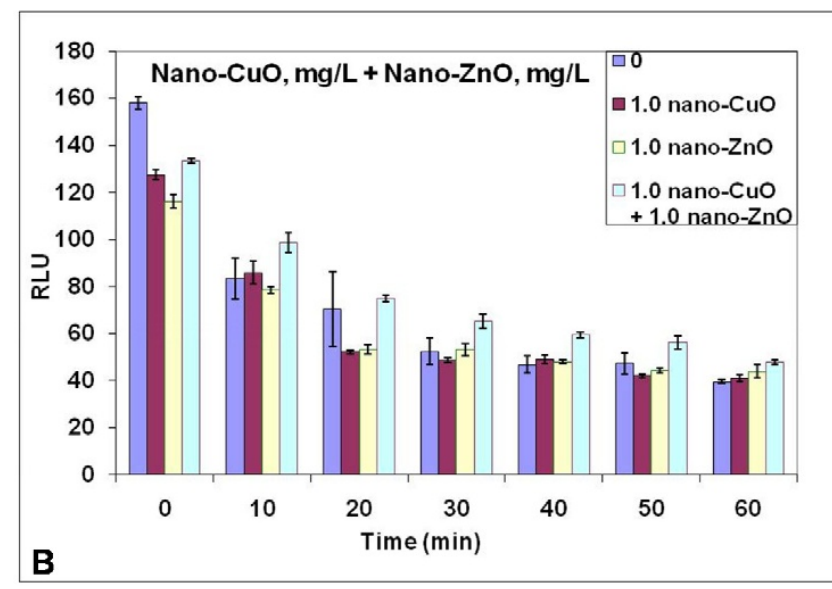

\begin{tabular}{|l|l|l|}
\hline $\begin{array}{l}\text { Nano-CuO, } \mathrm{mg} / \mathrm{L}+ \\
\text { Nano-ZnO, } \mathrm{mg} / \mathrm{L}\end{array}$ & $\log _{10} \mathrm{Cfu} . / \mathrm{ml}$ & RLU at $60 \mathrm{~min}$ \\
\hline Control & $8.6 \pm 0.0$ & $39.4 \pm 1.2$ \\
\hline 1.0 nano-CuO & $8.6 \pm 0.0$ & $41.1 \pm 2.4$ \\
\hline 1.0 nano-ZnO & $9.1 \pm 0.0$ & $43.9 \pm 5.1$ \\
\hline $\begin{array}{l}1.0 \text { nano-CuO + } \\
1.0 \text { nano-ZnO }\end{array}$ & $8.1 \pm 0.0$ & $47.7 \pm 1.8$ \\
\hline
\end{tabular}

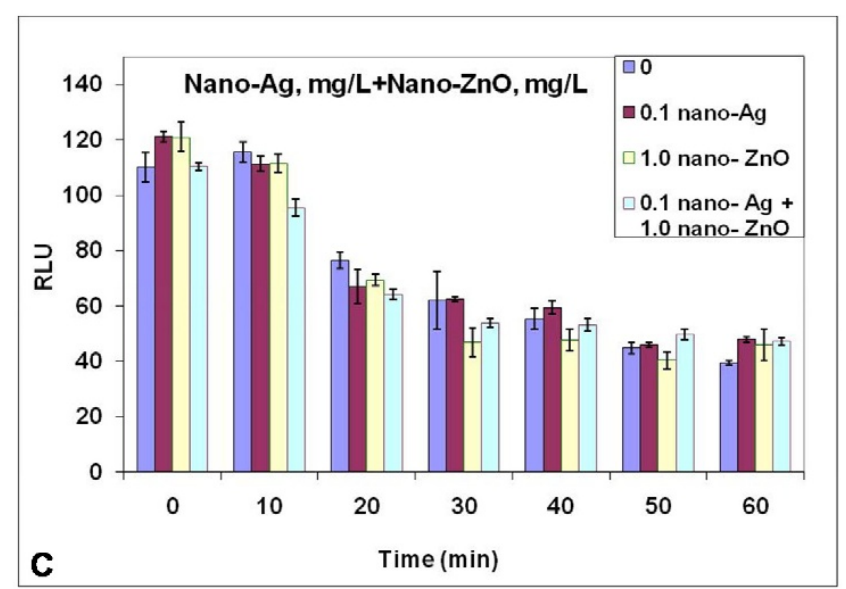

\begin{tabular}{|l|l|l|}
\hline $\begin{array}{l}\text { Nano-Ag, } \mathrm{mg} / \mathrm{L}+ \\
\text { Nano-ZnO, } \mathrm{mg} / \mathrm{L}\end{array}$ & Log $_{10} \mathrm{Cfu} . / \mathrm{ml}$ & $\mathrm{RLU}$ at $60 \mathrm{~min}$ \\
\hline Control & $8.7 \pm 0.0$ & $39.5 \pm 1.6$ \\
\hline 0.1 nano-Ag & $9.5 \pm 0.0$ & $48.0 \pm 1.7$ \\
\hline 1.0 nano-ZnO & $9.1 \pm 0.0$ & $46.0 \pm 9.9$ \\
\hline $\begin{array}{l}\text { 0.1 nano-Ag + 1.0 } \\
\text { nano-Zno }\end{array}$ & $7.9 \pm 0.0$ & $47.2 \pm 2.5$ \\
\hline
\end{tabular}

Figure 4

Response of the $P$ putida KT2440 biosensor to combinations of nano-Ag, nano-CuO and nano-ZnO at defined doses of $\mathrm{mg} \mathrm{Ag} / \mathrm{L}$ and $\mathrm{mg} \mathrm{Cu} / \mathrm{L}$. Changes in Lux output (Relative light units RLU) and cell culturability (colony forming units $\mathrm{Cfu}$ ) are shown. Studies were performed as described in Methods. NCD = No culturable cells detected. Data are from one study typical of at least three generated under the same conditions. Means and standard errors are shown. 

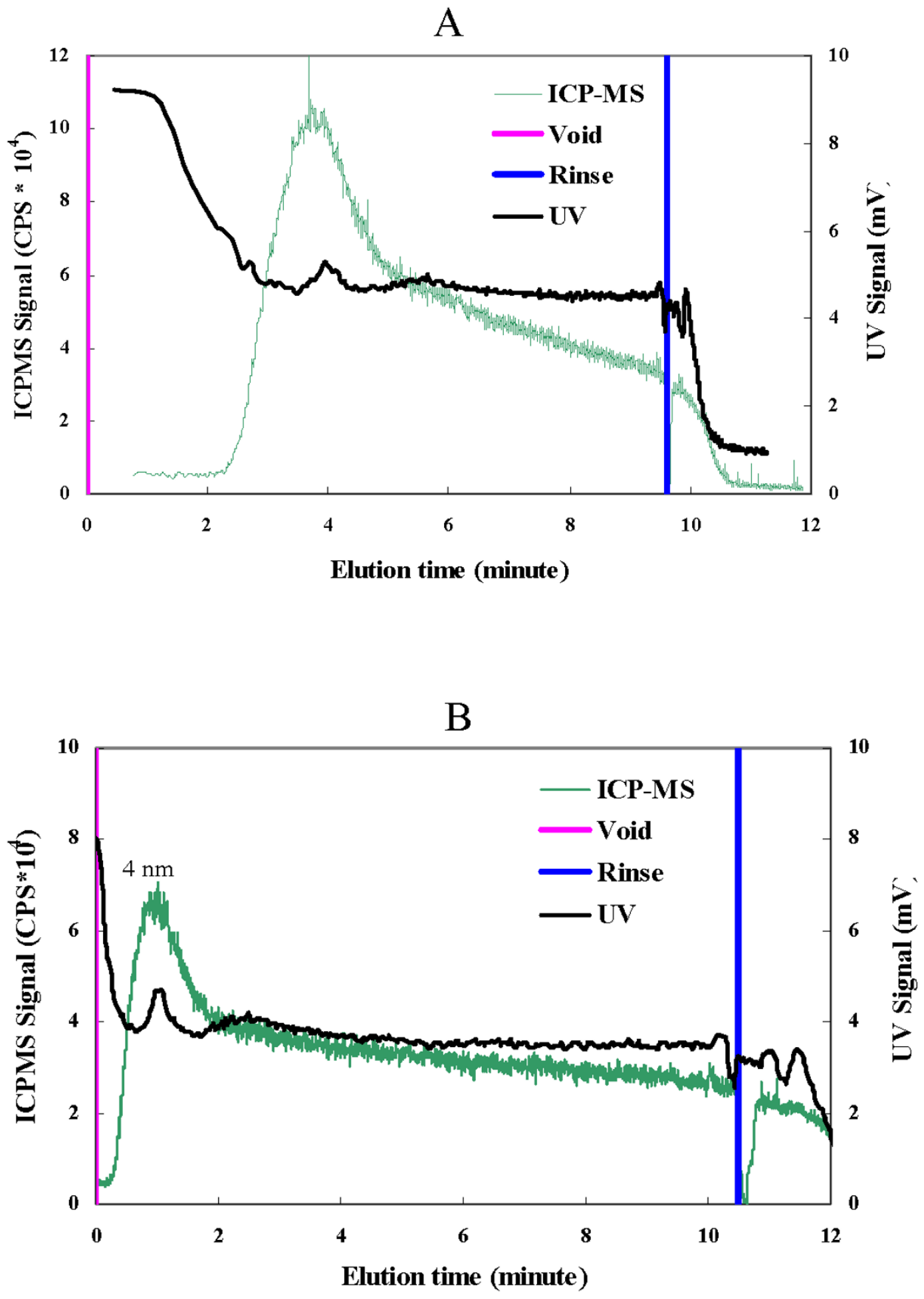

Figure 5

Fractogram of materials remaining on the filter of a $450 \mathrm{~nm}$ filter as assessed by ICP-MS and UV signal for nano-CuO (A) and nano-ZnO (B) sampled under FIFFF condition II (Table I), elution time was adjusted by the void peak. 

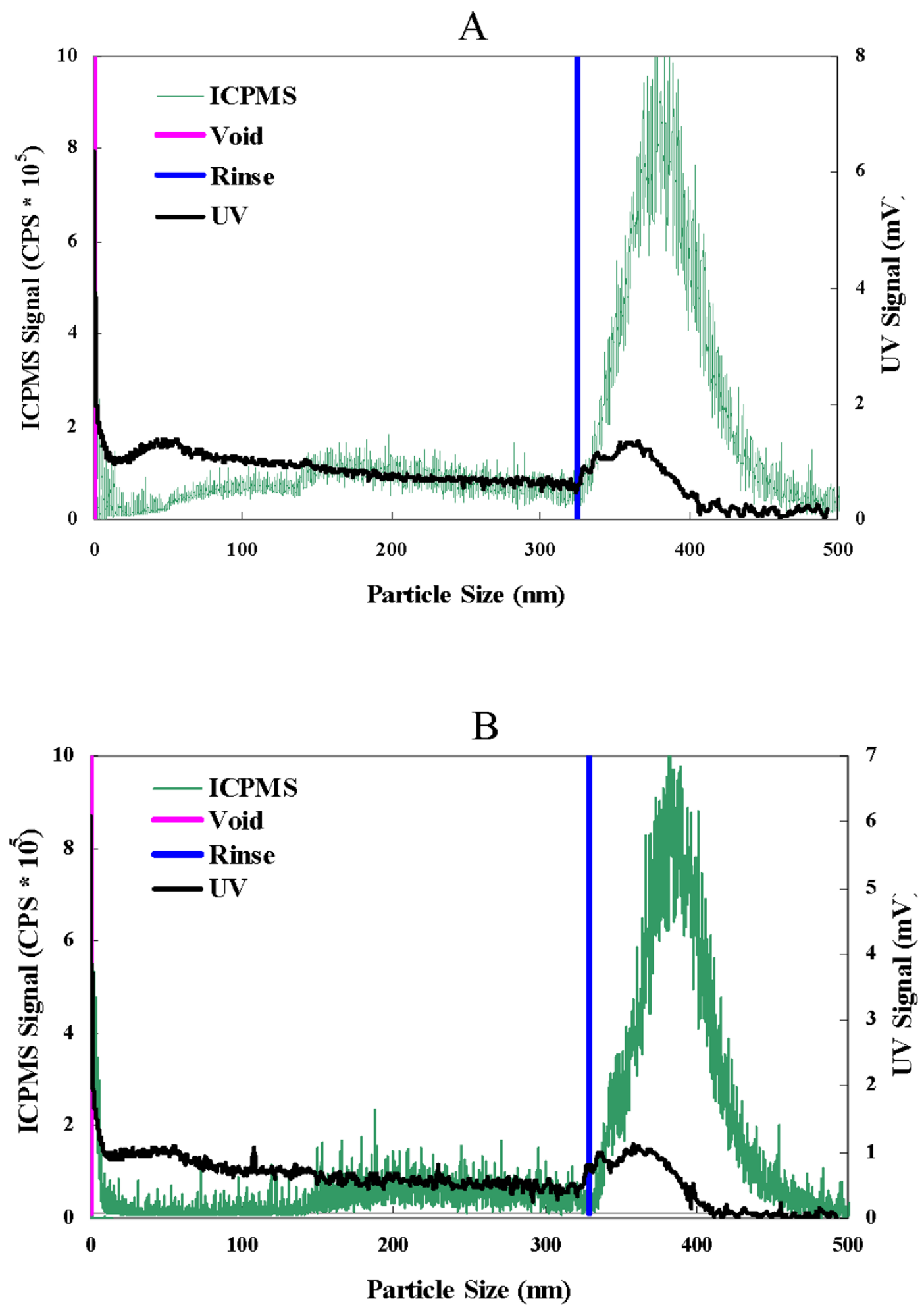

Figure 6

Fractogram of materials present in the $450 \mathrm{~nm}$ filtrate of nano-CuO (A) and nano-ZnO (B) as assessed by ICPMS and UV signal under FIFFF condition I (Table I). Elution particle size was adjusted by the void peak. 
Using nano- $\mathrm{CuO}$ and nano-ZnO from sources different from our own, nano- $\mathrm{ZnO}$ was more toxic than nano- $\mathrm{CuO}$ for Vibrio fischeri [17], compared with similar toxicity with for KT2440. Combinations of nano-Ag and nano-ZnO or nano- $\mathrm{CuO}$ and nano- $\mathrm{ZnO}$ were not interactive. However, the combination of nano-Ag plus nano-CuO was more inhibitory than their effects alone and the decrease in Lux correlated with reduction in culturability. These findings suggest that the target sites for nano-Ag and nano- $\mathrm{CuO}$ differed.

Toxicity as assessed with the pseudomonad biosensor was at lower NP levels than observed in other assays where culturability on solid or liquid media was the bioassay. For instance, in assays in rich medium, nano- $\mathrm{ZnO}$ toxicity required $126 \mathrm{mg} \mathrm{Zn/L} \mathrm{with} S$. aureus [18] and for E. coli and B. subtilis $70 \mathrm{mg} / \mathrm{L}$ for nano-Ag [5] compared with 7$10 \mathrm{mg} \mathrm{Zn/L} \mathrm{from} \mathrm{nano-ZnO} \mathrm{and} 0.3 \mathrm{mg} \mathrm{Ag} / \mathrm{L}$ for the pseudomonad. The KT2440 bioassays were performed under conditions with no other added metal ions, thus, limiting possible competition with the heavy metal for bacterial binding sites. Likewise, the inorganic and organic materials that compose most bacterial growth media were not present. Such materials might otherwise complex the metals and change bioavailability.

Size and, thus, aggregation of the NP are important in nanotoxicity. For nano- $\mathrm{ZnO}$, particles of $8 \mathrm{~nm}$ in size were more toxic to $S$. aureus than those that were reported to be larger $(50-70 \mathrm{~nm})$; these latter products were from the same Sigma-Aldrich source that we used [18]. Thus, it is interesting that we observed by FlFFF that $5 \mathrm{~nm}$ NP were present in the nano-CuO and- $\mathrm{ZnO}$ preparations. Exposing the biosensor to filtrates of nano-CuO and $\mathrm{ZnO}$ that would contain such particles showed dose dependent effects on light output and cell culturability. The FlFFF fractograms also showed that the aqueous NP suspensions prepared from manufactured NP powders were aggregated into poly-dispersed particulates ranging in size range from $70 \mathrm{~nm}$ to larger than $300 \mathrm{~nm}$, with the majority of the $\mathrm{Cu}$ and $\mathrm{Zn}$ mass being associated with the larger particles.

Unlike the treatments with $\mathrm{Cu}$ or $\mathrm{Ag}$, nonlethal doses of zinc from bulk, nano- $\mathrm{ZnO}$ and the ion increased light output above the control in the bioassays. To explore whether this was due to $\mathrm{Zn}$ activation of the promoter of the PP_0588 locus, we added zinc to a biosensor prepared with the fusion of the same luxAB-npt cassette to the promoter of the pseudomonad catalase gene. No increase in light output was observed with addition of $\mathrm{Zn}$ in this construct where the promoter region lacked a metal-sensitive motif (data not shown). These findings suggest that increased Lux activity with the KT2440 biosensor by Zn was promoter-driven, in agreement with the existence of a heavy metal-sensitive element in the promoter of the PP_0588 used in biosensor construct. Also, in the biosensor KT2240 strain we observed zinc caused bacteriostasis. Two other studies report that nano- $\mathrm{ZnO}$ was bacteriostatic to Streptococcus and Staphylococcus isolates in both broth medium or on solid agar plates $[18,42]$. Additionally the antimicrobial effect of nano-ZnO was reported to be sensitive to activation by the UV-radiation from laboratory lighting [18], conditions under which our assays were performed. Other studies on toxicity of nano-ZnO to mammalian cells found that solubilization of nano- $\mathrm{ZnO}$ as well as release of $\mathrm{Zn}$ ions from the NP contributed to activity [43].

Our observations confirmed that the biosensor generated with Lux as the output signal was a sentinel for cellular toxicity. Similar bacterially-based biosensors have been used previously to examine the toxicity of $\mathrm{Cu}$ and $\mathrm{Zn}$ in sludges [44]. Collectively, our findings show that NP preparations containing the heavy metals $\mathrm{Ag}$, $\mathrm{Cu}$ and $\mathrm{Zn}$ were toxic to the beneficial environmental microbe, $P$. putida KT2440, suggesting that the NP at certain concentrations ( $\leq 1 \mathrm{mg} \mathrm{Ag} / \mathrm{L}, \approx 10 \mathrm{mg} \mathrm{Cu}, \mathrm{Zn} / \mathrm{L})$ can be an environmental risk. The impact of the nano-metal oxides on cell culturability was dependent on the chemistry of the particles, with $\mathrm{Zn}$ causing bacteriostasis whereas $\mathrm{Cu}$ and Ag were bactericidal. FlFFF of the aqueous suspensions of the nano-metal oxides showed most of the mass was in aggregates greater than $300 \mathrm{~nm}$ although these ranged downward with another peak at $5 \mathrm{~nm}$. Our findings suggest that further studies on determining the factors that affect aggregation of commercial NP in the environment are required. It is likely that such aggregation would reduce the deleterious effect of as-made NP on nontarget microbes. Implementing conditions promoting NP aggregation could alleviate point-source contamination.

\section{Competing interests}

The authors declare that they have no competing interests.

\section{Authors' contributions}

Experimental design and final analysis were conducted by AJA, WPG, and DWB. PG, AJA and BP carried out the Lux experiments. WH and WPJ carried out the FlFFF experiments. All authors contributed to writing the manuscript and have approved the final manuscript.

\section{Acknowledgements}

We thank Dr. CD Miller and Chun Zhang MS for providing the biosensor construct. AJA acknowledges the EPA for a STAR-grant on risk assessment of heavy metals that initiated the construction of the biosensor. DWB and AJA thank the Utah Agricultural Experiment Station for support. DWB, AJA, and WPJ gratefully acknowledge support from USDA-CSREES grant 2009-35603-05037. AES Experimental Journal Paper Number 8008. 


\section{References}

I. Mueller NC, Nowack B: Exposure modeling of engineered nanoparticles in the environment. Environ Sci Technol 2008 , 42( 12 ):4447-4453.

2. Blaser SA, Scheringer M, Macleod M, Hungerbühler K: Estimation of cumulative aquatic exposure and risk due to silver: contribution of nano-functionalized plastics and textiles. Sci Total Environ 2008, 390(2-3):396-409.

3. AmericanElements: Silver Nanoparticles. 2007 [http://www.amer icanelements.com/agnp.html].

4. Adams LK, Lyon DY, Alvarez PJ: Comparative eco-toxicity of nanoscale $\mathrm{TiO}_{2}, \mathrm{SiO}_{2}$ and $\mathrm{ZnO}$ water suspensions. Water Res 2006, 40(I9):3527-3532.

5. Yoon KY, Hoon Byeon J, Park JH, Hwang J: Susceptibility constants of Escherichia coli and Bacillus subtilis to silver and copper nanoparticles. Sci Total Environ 2007, 373(2-3):572-575.

6. Reddy KM, Feris K, Bell J, Wingett DG, Hanley C, Punnoose A: Selective toxicity of zinc oxide nanoparticles to prokaryotic and eukaryotic systems. Appl Phys Lett 2007, 90(2 | 3902):2 | 3902 |-2139023.

7. Stohs S], Bagchi D: Oxidative mechanisms in the toxicity of metal ions. Radic Biol Med. 1995, I 8(2):32I-336.

8. Cioffi N, Torsi L, Ditaranto N, Tantillo G, Ghibelli L, Sabbatini L, Bleve-Zacheo T, D'Alessio M, Zambonin PG, Traversa E: Copper nanoparticle/polymer composites with antifungal and bacteriostatic properties. Chem Mater 2005, 1 7:5255-5262.

9. Kim JS, Kuk E, Yu KN, Kim JH, Park S], Lee HJ, Kim SH, Park YK, Park YH, Hwang CY, Kim YK, Lee YS, Jeong DH, Cho MH: Antimicrobial effects of silver nanoparticles. Nanomedicine 2007 3(I):95-10I

10. Lok CN, Ho CM, Chen R, He QY, Yu WY, Sun H, Tam PK, Chiu JF, Che CM: Proteomic analysis of the mode of antibacterial action of silver nanoparticles. J Proteome Res 2006, 5(4):9| 6-924.

II. Pal S, Tak YK, Song JML: Does the antibacterial activity of silver nanoparticles depend on the shape of the nanoparticle? $A$ study of the Gram-negative bacterium Escherichia coli. App Environ Microbiol 2007, 73(6): I7I2-I720.

12. Shahverdi AR, Fakhimi A, Shahverdi HR, Minaian S: Synthesis and effect of silver nanoparticles on the antibacterial activity of different antibiotics against Staphylococcus aureus and Escherichia coli. Nanomedicine 2007, 3(2): I68-I7I.

13. Sondi I, Salopek-Sondi B: Silver nanoparticles as antimicrobial agent: a case study on Escherischia coli as a model for Gramnegative bacteria. J Colloid Interface Sci 2004, 275(I): I77-I82.

14. Gogoi SK, Gopinath P, Paul A, Ramesh A, Ghosh SS, Chattopadhyay A: Green fluorescent protein-expressing Escherichia coli as a model system for investigating the antimicrobial activities of silver nanoparticles. Langmuir 2006, 22(22):9322-9328.

15. Panacek A, Kvítek L, Prucek R, Kolar M, Vecerova R, Pizùrova N Sharma VK, Nevecna T, Zboril R: Silver colloid nanoparticles: synthesis, characterization, and their antibacterial activity. Phys Chem B 2006, I I 0(33): I6248-I6253.

16. Ruparelia JP, Chatterjee AK, Duttagupta SP, Mukherji S: Strain specificity in antimicrobial activity of silver and copper nanoparticles. Acta Biomater. 2008, 4(3):707-7l6.

17. Heinlaan M, Ivask A, Blinova I, Dubourguier HC, Kahru A: Toxicity of nanosized and bulk $\mathrm{ZnO}, \mathrm{CuO}$ and $\mathrm{TiO}(2)$ to bacteria Vibrio fischeri and crustaceans Daphnia magna and Thamnocephalus platyurus. Chemosphere 2008, 7 I(7): I308-1316.

18. Jones N, Ray B, Ranjit KT, Manna AC: Antibacterial activity of ZnO nanoparticle suspensions on a broad spectrum of microorganisms. FEMS Microbiol Lett 2008, 279(I):71-76.

19. Nweke CO, Alisi CS, Okolo JC, Nwanyanwu CE: Toxicity of Zinc to heterotrophic bacteria from a tropical river sediment. Applied Ecology and Environmental Research 2007, 5(I): | 23-I32

20. Nguyen TMP, Phan TN, Robert EM: Zinc effects on oxidative physiology of oral bacteria. Advances in Natural Sciences 2006 7:131-138

21. Beard SJ, Hughes MN, Poole RK: Inhibition of the cytochrome bd-terminated NADH oxidase system in Escherichia coli K-I 2 by divalent metal cations. FEMS Microbiol Lett 1995 I 3 |(2):205-2 I0.

22. Mills DA, Schmidt B, Hiser C, Westley E, Ferguson-Miller S: Membrane potential-controlled inhibition of cytochrome c oxidase by zinc. J Biol Chem 2002, 277(I7): |4894-|490I.
23. Feng QL, Wu J, Chen GQ, Cui FZ, Kim TN, Kim JO: A mechanistic study of the antibacterial effect of silver ions on Escherichia coli and Staphylococcus aureus. J Biomed Mater Res 2000, 52(4):662-668.

24. Holt KB, Bard AJ: Interaction of silver (I) ions with the respiratory chain of Escherichia coli: an electrochemical and scanning electrochemical microscopy study of the antimicrobial mechanism of micromolar. Biochemistry. 2005, 44(39): I32| $4-\mid 3223$

25. Molina MA, Ramos JL, Espinosa-Urgel M: A two-partner secretion system is involved in seed and root colonization and iron uptake by Pseudomonas putida KT2440. Environ Microbiol 2006 8(4):639-647.

26. Osler $\mathrm{GH}$, Sommerkorn $\mathrm{M}$ : Toward a complete soil $\mathbf{C}$ and $\mathbf{N}$ cycle: incorporating the soil fauna. Ecology 2007 88(7): $|6||-| 62 \mid$

27. Kertesz MA, Mirleau P: The role of soil microbes in plant sulphur nutrition. J Exp Bot 2004, 55(404): 1939-1945.

28. Khan AG: Role of soil microbes in the rhizospheres of plants growing on trace metal contaminated soils in phytoremediation. J Trace Elem Med Biol 2005, I 8(4):355-364.

29. Gupta A, Gopal M, Tilak KV: Mechanism of plant growth promotion by rhizobacteria. Indian J Exp Biol 2000, 38(9):856-862.

30. Dos Santos VA, Heim S, Moore ER, Strätz M, Timmis KN: Insights into the genomic basis of niche specificity of Pseudomonas putida KT2440. Environ Microbiol 2004, 6( I 2): I 264-I 286.

31. Van Wees SC, Ent S Van der, Pieterse CM: Plant immune responses triggered by beneficial microbes. Curr Opin Plant Biol 2008, I I (4):443-448.

32. Nowack B, Bucheli TD: Occurrence, behavior and effects of nanoparticles in the environment. Environ Pollut 2007, I 50(I):5-22.

33. Benn TM, Westerhoff $P$ : Nanoparticle silver released into water from commercially available sock fabrics. Environ Sci Technol 2008, 42(I I):4I33-4I39.

34. Eckelman MJ, Graedel TE: Silver emissions and their environmental impacts: a multilevel assessment. Environ Sci Technol 2007, 4 I ( I 7):6283-6289.

35. Ramos-González MI, Campos MJ, Ramos JL: Analysis of Pseudomonas putida KT2440 gene expression in the maize rhizosphere: in vivo expression technology capture and identification of root-activated promoters. I Bacteriol 2005 , | 87( I 2):4033-404 I

36. Child R, Miller CD, Liang Y, Narasimham G, Chatterton J, Harrison P, Sims RC, Britt D, Anderson AJ: Polycyclic aromatic hydrocarbon-degrading Mycobacterium isolates: their association with plant roots. Appl Microbiol Biotechnol 2007, 75(3):655-663.

37. Koga K, Harada T, Shimizu H, Tanaka K: Bacteria luciferase activity and the intracellular redox pool in Escherichia coli. Mol Genet Genomics 2005, 274(2): I80-188.

38. Giddings JC: Field-flow fractionation. Separ Sci Technol 1985 | 9 ( I | \& | 2):83 |-847.

39. Giddings JC: Field-flow fractionation: Analysis of macromolecular, colloidal and particulate materials. Science 1993, 260(5 I I 3): | 456- | 465.

40. Prestel H, Schott L, Niessner R, Panne U: Characterization of sewage plant hydrocolloids using asymmetrical flow field-flow fractionation and ICP-mass spectrometry. Water Res 2005 , 39(I 5):354I-3552.

4I. Litzén A: Separation speed, retention, and dispersion in asymmetrical flow field-flow fractionation as functions of channel dimensions and flow rates. Analytical Chemistry 1993, 65(5):46I-470.

42. Huang $Z$, Zheng $X$, Yan D, Yin G, Liao $X$, Kang $Y$, Yao $Y$, Huang D, Hao B: Toxicological effect of $\mathrm{ZnO}$ nanoparticles based on bacteria. Langmuir 2008, 24(8):4|40-4|44.

43. Xia T, Kovochich M, Liong M, Mädler L, Gilbert B, Shi H, Yeh ll, Zink $\mathrm{Jl}, \mathrm{Nel} A \mathrm{E}$ : Comparison of the mechanism of toxicity of zinc oxide and cerium oxide nanoparticles based on dissolution and oxidative stress properties. ACS Nano 2008, 2:2 I 2 I-2I 34 .

44. Chaudri AM, Lawlor K, Preston S, Paton GI, Kikkham K, McGrath SP: Response of a Rhizobium-based luminescence biosensor to $\mathrm{Zn}$ and $\mathrm{Cu}$ in soil solutions from sewage sludge treated soils. Soil Biology and Biochemistry 2000, 32:383-388. 